\title{
Chemical composition and cytotoxicity activity of the essential oil of Pterodon emarginatus
}

\author{
Rafael C. Dutra, ${ }^{*}, 1,2$ Frederico Pittella, ${ }^{1}$ Dalton Dittz, ${ }^{3}$ Rodrigo \\ Marcon, ${ }^{2}$ Daniel S. Pimenta, ${ }^{4}$ Miriam T. P. Lopes, ${ }^{3}$ Nádia R. B. \\ $\operatorname{Raposo}^{1}$
}

${ }^{I}$ Núcleo de Identificação e Quantificação Analítica, Universidade Federal de Juiz de Fora, Brazil,

${ }^{2}$ Departamento de Farmacologia, Universidade Federal de Santa Catarina, Brazil, ${ }^{3}$ Laboratório de Substâncias Antitumorais, Universidade Federal de Minas Gerais, Brazil,

${ }^{4}$ Departamento de Botânica, Instituto de Ciências Biológicas, Universidade Federal de Juiz de Fora, Brazil.
Revista Brasileira de Farmacognosia Brazilian Journal of Pharmacognosy 22(5): 971-978, Sep./Oct. 2012

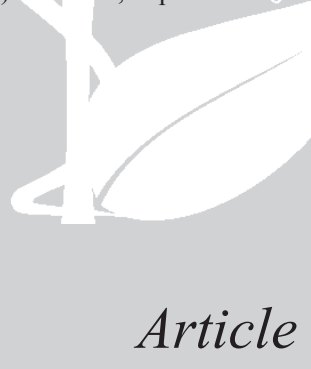

Received 10 Sep 2011

Accepted 19 Jan 2012 Available online 3 Apr 2012

\begin{abstract}
Pterodon emarginatus Vogel, Fabaceae, is a native aromatic tree distributed by central region of Brazil. Hydroalcoholic infusions of the seeds are used in folk medicine for their anti-rheumatic and anti-inflammatory properties. The objective of this work was identified the chemical components and verify the cytotoxic effect of the essential oil (EO) from P. emarginatus seeds. Thus, the EO of $P$. emarginatus seeds was analyzed by GC/MS analysis followed by brine shrimp lethality test and cytotoxic activity against tumor cell lines and human peripheral mononuclear blood cells (PBMC). The cancer cell lines tested were $\mathrm{C}_{6}$ (rat glioma), MeWo (human melanoma), $\mathrm{CT}_{26}$. WT (mouse colon carcinoma), MDA (human breast cancer), $\mathrm{A}_{549}$ (human lung carcinoma), $\mathrm{B}_{16}-\mathrm{F}_{1}$ (mouse melanoma), $\mathrm{CHO}-\mathrm{K} 1$ (hamster ovary cell) and BHK21 (hamster kidney fibroblast). Eleven compounds were identified by GC and $\mathrm{CG} / \mathrm{MS}$ analyses. The main compounds with concentrations higher than $5 \%$ were $\beta$-elemene $(15.3 \%)$, trans-caryophyllene $(35.9 \%)$, $\alpha$-humulene $(6.8 \%)$, germacrene-D (9.8\%), bicyclo germacrene (5.5\%) and spathulenol (5.9\%). The EO of P. emarginatus seeds showed toxicity to Artemia salina (LC50 1.63 $\mu \mathrm{g} / \mathrm{mL}$ ) and was active against all the cell lines tested. The potent cytotoxic activity had IC50 values ranging from 24.9 to $47 \mu \mathrm{g} / \mathrm{mL}$. However, EO (1-100 $\mu \mathrm{g} / \mathrm{mL}$ ) had less cytotoxicity in PBMCs isolated from a healthy subject. In summary, the present study showed the potential antiproliferative of the EO of P. emarginatus seeds.
\end{abstract}

ISSN 0102-695X http://dx.doi.org/10.1590/S0102 $695 \times 2012005000042$

\section{Introduction}

Medicinal plants have been a useful source for the research of new biologically active compounds. There have been worldwide efforts to discover new antitumoral compounds from plants (Kamuhabwa et al., 2000). Different approaches are used to select a plant for research, specially the ethnomedical data. However, ethnomedical data obtained of a plant used to treat cancer might not be reliable, since it is difficult to be well diagnosed (Cragg et al., 1994). Apart from the medicinal effects of traditional herbs, exploratory researches have been made and a wide variety of new biological activities from traditional medicinal plants have recently been reported, including anticancer activity (Yoo et al., 2007).
Pterodon emarginatus Vogel, Fabaceae, known in Brazil as "sucupira-branca" or "faveiro", is a native aromatic tree reaching the height of 5-10 $\mathrm{m}$ and distributed by all central region of Brazil (Goiás, Minas Gerais and São Paulo) (Lorenzi \& Matos, 2002). Hydroalcoholic infusions of the seeds are used in folk medicine for their anti-rheumatic, analgesic and anti-inflammatory properties (Brito \& Brito, 1993; Duarte et al., 1996). Chemical studies on genus Pterodon have shown the presence of alkaloid compounds in the bark (Torrenegra et al., 1989), isoflavone and some triterpenes in the wood (Marques et al., 1998), diterpenes (Fascio et al., 1976; Arriaga et al., 2000) and isoflavones in seed oil (Braz-Filho et al., 1971). The diterpene 14,15-epoxygeranylgeraniol and some derivatives isolated of $P$. pubenscens have been associated with protective activity against the penetration 
of cercarias of Schistossoma mansoni, a typically tropical disease (Dos Santos Filho et al., 1972). The furane diterpene $6 \alpha, 7 \beta$-dihydroxyvouacapan-17-oate sodium, isolated from the oil of the fruits of P. polygalaeflorus Benth, presented anti-inflammatory activity on the test in rats leg edema induced by carrageenan (Silva et al., 2004).

Recently, Vieira et al. (2008) showed the crude ethanolic extract and furane diterpene, isolated from $P$. pubescens seeds, inhibited human melanoma cell line SK MEL cell growth. In this same study, the subfraction A (fractionation by gradient elution with hexane/ethyl acetate-80:20) caused morphological features and internucleosomal DNA fragmentation pattern of apoptosis (Vieira et al., 2008). These results have led authors to conclude that diterpenoids vouacapan-type skeleton could be used as a model to develop new anticancer agents. This evidence has been further extended by recent results showing that $6 \alpha, 7 \beta$-hydroxyvouacapan-17 $\beta$-lactone inhibited the growth of human cancer cells (Euzébio et al., 2009). These findings were recently confirmed by Pereira et al. (2011), who have demonstrated that methyl$6 \alpha$-acetoxy-7 $\beta$-hydroxyvouacapan-17 $\beta$-oate

(SF5) significantly induced cytotoxic and anti-proliferative effects on K562 cells. Moreover, down-regulation of DNA (cytosine-5)-methyltransferase 1 (DNMT1) gene transcription and over-expression of apoptotic protease activating factor 1 (Apaf-1) mRNA suggested that SF5 may be inducing apoptosis of K562 cells by epigenetic up-regulation of pro-apoptotic proteins involved in the mitochondrial intrinsic pathway (Pereira et al., 2011).

However, there have been no reports about the effects of EO from P. emarginatus on the growth of human and/or non-human cancer cells. In the present study, we sought to investigate the cytotoxicity activity of the EO of $P$. emarginatus seeds and attempted to elucidate some of the mechanisms through which EO modulates the growth of cancer cells. For this reason, the EO chemical composition, brine shrimp lethality test and in vitro cytotoxic activity against some cancer cell lines were evaluated.

\section{Material and Methods}

\section{Plant material and EO isolation}

Plant material (seeds) of the species Pterodon emarginatus Vogel, Fabaceae, was collected in September 2006 at the city of Três Marias (Minas Gerais, Brazil) and authenticated by Dr. Fátima Regina Gonçalves Salimena from the Departamento de Botânica, Universidade Federal de Juiz de Fora (UFJF), Brazil. A voucher specimen ( $\mathrm{N}^{\circ}$ 48.077) has been deposited at Herbarium CESJ of the Universidade Federal de Juiz de Fora (Minas Gerais, Brazil). The seeds of $P$. emarginatus were triturated (30 g) and hydrodistilled in a Clevenger-type apparatus. After $2 \mathrm{~h}$ distillation, the EO was collected as a film floating on the surface of water. The samples were sealed and kept in dark glass vials in the refrigerator at $4{ }^{\circ} \mathrm{C}$ for further analysis.

\section{Chemical composition of EO}

\section{Gas chromatography (GC)}

The essential oils were analyzed using a gas chromatograph (model 8700, PerkinElmer, Norwalk, CT, USA) equipped with flame ionization detector (FID) and HP-5 MS capillary column $(30 \mathrm{~m} \times 0.25 \mathrm{~mm}$, film thickness $0.25 \mu \mathrm{m})$. Injector and detector temperatures were set at 220 and $290{ }^{\circ} \mathrm{C}$, respectively. Column oven temperature was programmed from 80 to $240{ }^{\circ} \mathrm{C}$ at a rate of $4{ }^{\circ} \mathrm{C} / \mathrm{min}$; initial and final temperatures were held for 3 and $10 \mathrm{~min}$, respectively. Helium was used as carrier gas with a flow rate of $1.5 \mathrm{~mL} / \mathrm{min}$. A sample of $1.0 \mu \mathrm{L}$ was injected using the split mode (split ratio 1:100). All quantification was done using a built-in datahandling program provided by the manufacturer of the gas chromatograph (PerkinElmer). The composition was reported as relative percentage of the total peak area.

Gas chromatography-mass spectrometry (GCMS) and compound identification

GC-MS analysis of the essential oils was performed using an Agilent Technologies (Little Falls, CA, USA) $6890 \mathrm{~N}$ network GC system, equipped with an Agilent Technologies 5975 Inert XL mass selective detector and 7683B series auto-injector. Compounds were separated on an HP-5 MS capillary column (30 m $\times 0.25 \mathrm{~mm}$, film thickness $0.25 \mu \mathrm{m}$ ). A $1.0 \mu \mathrm{L}$ sample was injected in the split mode, with a split ratio of 1:100. For GC-MS detection, an electron ionization system with ionization energy of $70 \mathrm{eV}$ was used. Column oven temperature programmed was the same as in GC analysis. Helium was used as a carrier gas at a flow rate of $1.5 \mathrm{~mL} / \mathrm{min}$. Mass range was $50-550 \mathrm{~m} / \mathrm{z}$, while the injector and MS transfer line temperatures were set at 220 and $290{ }^{\circ} \mathrm{C}$, respectively. Most constituents were identified by gas chromatography by comparison of their GC retention indices with those of the literature or with those of standards available in our laboratories. The retention indices were determined in relation to a homologous series of n-alkanes (C8-C24) under the same operating conditions. Further identification was made by comparison of their mass spectra on both columns with those stored in NIST 98 and Wiley 5 Libraries or with mass spectra from literature (Adams, 1995).

\section{Brine shrimp lethality test}


The assay was carried out according Meyer et al. (1982). Artemia salina Leach eggs were cultured in artificial sea water: $\mathrm{NaCl} 24.0 \mathrm{~g} / \mathrm{L}, \mathrm{CaCl}_{2} .2 \mathrm{H}_{2} \mathrm{O} 1.5 \mathrm{~g} / \mathrm{L}$, $\mathrm{KBr} 0.1 \mathrm{~g} / \mathrm{L}, \mathrm{KCl} 0.7 \mathrm{~g} / \mathrm{L}, \mathrm{Na}_{2} \mathrm{SO}_{4} 4.0 \mathrm{~g} / \mathrm{L}, \mathrm{NaHCO}_{3} 0.3$ $\mathrm{g} / \mathrm{L}, \mathrm{MgCl}_{2} \cdot 6 \mathrm{H}_{2} \mathrm{O} 11.0 \mathrm{~g} / \mathrm{L}$. EO was dissolved in Tween 80 and dimethyl sulfoxide (DMSO) $(1: 2, \mathrm{v} / \mathrm{v})$, and then in artificial sea water. Ten brine shrimp (A. salina) were transferred for test tubes containing the following concentrations of the EO: $0.5,1,5,10$ and $50 \mu \mathrm{g} / \mathrm{mL}$ $(\mathrm{n}=4)$. The tubes were kept in constant illumination and thymol was used as standard control. Living nauplii were counted after $24 \mathrm{~h}$ of exhibition to the oil. LC50 and 95\% confidence intervals were from the $24 \mathrm{~h}$ counts using the probit analysis method (Litchfield \& Wilcoxon, 1949). The final volume used of the solution of Tween 80 and $\operatorname{DMSO}(1: 2, \mathrm{v} / \mathrm{v})$ was also tested.

\section{Cell viability assay}

The following cell lines were used in this study: $\mathrm{C}_{6}$ (rat glioma), MeWo (human melanoma), $\mathrm{CT}_{26}$.WT (mouse colon carcinoma), MDA-MB 231 (human breast cancer), $\mathrm{A}_{549}$ (human lung carcinoma), $\mathrm{B}_{16}-\mathrm{F}_{1}$ (mouse melanoma), CHO-K1 (hamster ovary cell) and BHK21 (normal hamster kidney fibroblast). All cell lines used were obtained from the American Type Culture Collection (ATCC, Rockville MD). Cells were grown in RPMI 1640 medium (Sigma Chemical Co.) supplemented with $10 \%$ fetal bovine serum (FBS-Gibco). Cells were maintained in humidified $5 \% \mathrm{CO}_{2}$ atmosphere at $37^{\circ} \mathrm{C}$. The cytotoxic potential of the $\mathrm{EO}$ was evaluated using an MTT assay according to Denizot \& Lang (1986). An EO stock solution $(5 \mathrm{mg} / \mathrm{mL})$ in $0.05 \%$ DMSO and purified water was prepared, filtered in $0.22 \mu \mathrm{m}$ filter and stored at $-20{ }^{\circ} \mathrm{C}$ till use. Before the experiments, this stock solution was diluted with supplemented RPMI 1640 medium to obtain final test concentrations. Cells $\left(10^{3}\right.$ cells/well) were seeded in supplemented medium in 96well culture plates (Falcon, NJ, USA) and were incubated in a humidified atmosphere with $5 \% \mathrm{CO}_{2}, 37^{\circ} \mathrm{C}$, for $24 \mathrm{~h}$ until total adhesion to surface. The medium was replaced with fresh supplemented medium containing different concentrations of EO $(20-50 \mu \mathrm{g} / \mathrm{mL})$. Cells were then incubated at $37^{\circ} \mathrm{C}$ for $48 \mathrm{~h}$. After this time, the medium was newly refreshed with the same concentration of EO and the plate was incubated again for $72 \mathrm{~h}$. The time of analysis was chosen according to the method previously described (Qu et al., 2007; Huang et al., 2011; Rivest et al., 2011). After incubation time, $10 \mu \mathrm{L}$ of a $5 \mathrm{mg} /$ $\mathrm{mL}$ stock solution of MTT in PBS was added to each well containing the cells and incubated again for $4 \mathrm{~h}$. Then, the supernatant without cells was aspirated from each well and $100 \mu \mathrm{L}$ of dimethyl sulfoxide (DMSOSigma Chemical Co.) was added to dissolve the dark blue formazan crystals resulting from MTT reduction by homogenization in plate shaker. The extent of MTT reduction to formazan within cells was measured by absorbance at $600 \mathrm{~nm}$ using a scanning microplate reader (Stat Fax-2100, Awareness Tecn.). The final volume used to dissolve the EO was also tested. Cultures used as controls did not receive extract.

\section{Mononuclear cell isolation}

Peripheral blood mononuclear cells (PBMC) were isolated from the peripheral blood of healthy volunteers, and were immediately isolated by gradient centrifugation in Ficoll-Paque ${ }^{\mathrm{TM}}$ Plus (Amersham Biosciences, USA). The mixture was centrifuged under at $400 \times \mathrm{g}$ for $40 \mathrm{~min}$ at $18-20{ }^{\circ} \mathrm{C}$. The undisturbed lymphocyte layer was carefully transferred out. The lymphocyte was washed and pelleted down with three volumes of balanced salt solution for twice and resuspended RPMI 1640 medium supplemented with $10 \% \mathrm{v} / \mathrm{v}$ fetal bovine serum, HEPES $(20 \mathrm{nM}), 2$-mercapto ethanol, penicillin $(100 \mathrm{U} / \mathrm{mL})$ and streptomycin $(100$ $\mu \mathrm{g} / \mathrm{mL})$. The PBMC cells were incubated with different concentrations of EO (1-100 $\mu \mathrm{g} / \mathrm{mL})$ for 12,24 and 48 $\mathrm{h}$ at $37{ }^{\circ} \mathrm{C}$ in a humidified $5 \% \mathrm{CO}_{2}$ atmosphere. The cell survival fraction was determined with the MTT (3-[4,5-dimethylthiazol-2-yl]-2,5-diphenyltetrazolium bromide) dye-reduction assay, as described above.

\section{Statistical analysis}

Each experiment was performed at least in triplicate. The results were expressed as mean \pm SEM for the number of experiments. The percentages of inhibition of cell viability were calculated with the values of viability of cell exposed to the EO and with non-exposed cells, using the software GraphPad Prisma 4.0 (GraphPad Software, Inc.). Statistical significance was compared between each treated group and control by the Student's t-test. Results with $p<0.05$ were considered significant from control group. The $50 \%$ inhibitory concentrations for cellular population (IC50) were calculated by linear regression (SigmaPlot 10.0, Systat Software, Inc.) in the interval of the corresponding concentrations to the curve of MTT metabolization vs. log of the used concentrations.

\section{Results and Discussion}

EO has been found widely applications in many areas such as medicine and pharmaceutical, cosmetic, agricultural and food industries (Bakkali et al., 2008; Lukas et al., 2009). Therefore, nowadays the investigation of biological activities of EO from a range of aromatic plants has been one of the attractive research areas. This study has evaluated the chemical composition 
and cytotoxicity activity of EO of Pterodon emarginatus Vogel, Fabaceae, seeds commonly consumed in Brazil and elsewhere in the world. Here, a light white EO of $P$. emarginatus seeds was obtained in a yield of $3.9 \%(\mathrm{w} / \mathrm{w})$ fresh weight. The results of the GC and GC-MS analysis of the oil identified eleven compounds, as monoterpenes and sesquiterpenes, such as: $\delta$-elemene $(4.8 \%$; Retention time (RT), 15.64; Kovats index (KI), 1327), $\beta$-elemene (15.3\%; RT, 15.67; KI, 1380), trans-caryophyllene (35.9\%; RT, 18.16; KI, 1411), $\beta$-gurjunene (4.6\%; RT, 18.49; KI, 1423), $\alpha$-humulene (6.8\%; RT, 19.23; KI, 1449), $\gamma$-muurolene (2.7\%; RT, 19.44; KI, 1462), germacrene-D (9.8\%; RT, 19.97; KI, 1475), bicyclo germacrene (5.5\%; RT, 20.44; KI, 1492), spathulenol (5.9\%; RT, 22.53; KI, 1570), caryophyllene oxide (3.8\%; RT, 22.72; KI, 1577) and cis-farnesyl acetate (4.9\%; RT, 26.34; KI, 1815). Importantly, our results confirm and extend some previously published data (Dutra et al., 2009b). A predominance of sesquiterpene was found analyzing the chemical composition of EO from $P$. emarginatus seeds, being trans-caryophyllene the one in highest concentration. These findings are in agreement with those from Carvalho (2004), however the presence of $\alpha$-caryophyllene, diterpenes and isoflavones was not verified in the EO of the seeds of $P$. emarginatus, as previously described (Braz-Filho et al., 1971; Fascio et al., 1976; Arriaga et al., 2000).

The EO of $P$. emarginatus seeds showed a potent toxicity in Artemia salina with LC50 1.63 (1.341.99) $\mu \mathrm{g} / \mathrm{mL}$ (Table 1). It was about 250 times more toxic than thymol (LC50 $480.20 \mu \mathrm{g} / \mathrm{mL}$ ), which was used as a reference substance. In agreement with our data, a number of works indicates that thymol showed several biological activities, such as cytotoxicity (Buyukleyla \& Rencuzogullari, 2009), antifungal, genotoxic (Stammati et al., 1999) and antileishmanial (De Medeiros et al., 2011) effects. Moreover, recent published data showed that thymol significantly increased the sister chromatid exchange, especially at the lower concentrations (75 and $100 \mu \mathrm{g} / \mathrm{mL}$ ), induced both the chromosome aberration (CA) and frequency of micronucleus (MN), as well as dose-dependently decreased the nuclear division index (NDI) in human peripheral lymphocytes (Buyukleyla \& Rencuzogullari, 2009). Taken together, our data confirms that thymol is an adequate positive control and that the EO obtained from the seeds of $P$. emarginatus could be cytotoxic to Artemia salina probably by modification the structure of DNA, as well as thymol. However, further studies are necessary to investigate this hypothesis.

A growing amount of evidences point out $A$. salina assay as crucial for antiproliferative effect of many natural products (Pimenta et al., 2003). Furthermore, among the bioassays that seeks guidance for drug discovery the A. salina assay is considered efficient, fast, cheap, and requires only 2 to $20 \mathrm{mg}$ of compounds (Pimenta et al.,
2003; Ajaiyeoba et al., 2006). The reference methodology for the $A$. salina bioassay which indicates the concentration to inhibit $50 \%$ of cell growth (IC50) as being a tenth of the effective dose to kill $50 \%$ of the brine shrimp in its nauplii stage (ED50) was initially established by McLaughlin \& Rogers (1998). In fact, studies conducted with naturally extracts and substances purified confirm and further extend the proposition that A. salina is a suitable experimental model to assess cytotoxicity. For instance, a recent study has demonstrated that methanol extract of Vitex trifolia purpurea showed a significant cytotoxic activity in brine shrimp bioassay, with LC50 value $173 \mu \mathrm{g} / \mathrm{mL}$ (El-Sayed et al., 2011). Other studies have confirmed and extended our data. It has been shown that Tamarindus indica crude extract and fractions showed brine shrimp death percentages ranging from $86.70 \%$ to $3.30 \%$ (Nwodo et al., 2011). Moreover, a very interesting study conducted by Boehme et al. (2008) suggested that the leaf EO of Zanthoxylum rhoifolium and Zanthoxylum setulosum showed activity against $A$. salina (Boehme et al., 2008). Herein, our data further extended these studies and together we reported for the first time that EO obtained from $P$. emarginatus markedly showed a potent cytotoxic activity in brine shrimp lethality bioassay.

Table 1. In vitro toxicity of the seeds oil of Pterodon emarginatus in Artemia salina.

\begin{tabular}{lccc}
\hline Compound & $\begin{array}{c}\text { Concentration } \\
(\mu \mathrm{g} / \mathrm{mL})\end{array}$ & LC50 $(\mu \mathrm{g} / \mathrm{mL})$ & $\begin{array}{c}95 \% \text { confidence } \\
\text { interval }\end{array}$ \\
\hline essential oil & $0.5-50$ & 1.63 & $1.34-1.99$ \\
thymol & $10-1000$ & 480.20 & $337.3-683.5$ \\
\hline
\end{tabular}

Data are presented as mean $(n=4 /$ concentration $)$ and are representative of four independent experiments.

EO has been shown to exhibit cytotoxic activity generally without being mutagenic in various organisms (Bakkali et al., 2008; Stammati et al., 1999). Since the differential cytotoxicity is also a useful feature for potential antitumor agents, the antiproliferative effect of the EO from P. emarginatus was evaluated in both cancer and normal cell line by MTT assay based on cell viability. Moreover, the MTT assay is a sensitive, simple and reliable approach used to evaluate the cytotoxicity of plant-based products. The inhibitory effects of EO (IC50 values) are presented in Table 2, indicating that the tested P. emarginatus EO showed prominent cytotoxic activity against all cancer cell lines. The lowest value for IC50 was obtained for $\mathrm{C}_{6}$ cell line $(24.9 \mu \mathrm{g} / \mathrm{mL})$ while the highest value for IC50 was obtained for $\mathrm{A}_{549}$ cell line $(47.0 \mu \mathrm{g} / \mathrm{mL})$. On the other hand, the EO of $P$. emarginatus seeds did not display strong cytotoxic effect on freshly isolated normal PBMC with viability of $94 \pm 1.5 \%, 93 \pm 3.5 \%$ and $95 \pm 3.3 \%$, during 12,24 and $48 \mathrm{~h}$, at $100 \mu \mathrm{g} / \mathrm{mL}$, respectively (Table 3). Here, 
doxorubicin (DOXO) used as a positive control in this experiment, had the strong cytotoxic effect on PBMC cells (Table 3). Doxorubicin, a broad-spectrum antitumor antibiotic, has been one of the most extensively used agents in the chemotherapy regimens of cancer patients for the past thirty years (Weiss, 1992; Singal \& Iliskovic, 1998). Moreover, DOXO stabilize a transient DNAtopoisomerase II complex in which DNA strands are cut and covalently linked to the enzyme subunits (Burden \& Osheroff, 1998). Consequently, the stabilized complex results in DNA damage that is related to the cytotoxic effect (Kaufman, 1998; Brown \& Wouters, 1999). Based on these results, it is tempting to speculate that $\mathrm{EO}$ of $P$. emarginatus seeds could modulate the DNA damage of tumor cells without affecting normal cells. Nonetheless further studies are needed to better understand whether EO had effects on DNA damage (such as p53, Bcl-2, Bax, cytochrome $\mathrm{c}$, and caspases) or protein damage (such as thioredoxin and glutathione) in cancer cells.

Table 2. In vitro cell viability assay of EO of Pterodon emarginatus seeds on different cell lines.

\begin{tabular}{lcc}
\hline Cell lines & IC50 $(\mu \mathrm{g} / \mathrm{mL})$ & Taxol $^{\circledR}(\mu \mathrm{g} / \mathrm{mL})$ \\
\hline $\mathrm{B}_{16} \mathrm{~F}_{1}$ & 43.4 & $3.55 \times 10^{-6}$ \\
MDA-MB 231 & 33.5 & $6.71 \times 10^{-6}$ \\
$\mathrm{C}_{6}$ & 24.9 & $3.43 \times 10^{-6}$ \\
$\mathrm{MeWO}$ & 25.5 & $6.42 \times 10^{-6}$ \\
$\mathrm{CT}_{26}{ }$ WT & 32.0 & $3.26 \times 10^{-6}$ \\
$\mathrm{~A}_{549}$ & 47.0 & $6.03 \times 10^{-6}$ \\
$\mathrm{BHK}-21$ & 38.0 & $1.06 \times 10^{2}$ \\
$\mathrm{CHO}-\mathrm{K} 1$ & 25.2 & $3.04 \times 10^{3}$ \\
\hline
\end{tabular}

$\mathrm{C}_{6}$ (rat glioma), MeWo (human melanoma), $\mathrm{CT}_{26}$. WT (mouse colon carcinoma), MDA-MB-231 (human breast cancer), $\mathrm{A}_{549}$ (human lung carcinoma), $\mathrm{B}_{16}-\mathrm{F}_{1}$ (mouse melanoma), CHO-K1 (hamster ovary cell) and BHK-21 (normal hamster kidney fibroblast). Data are presented as mean $(n=3 /$ concentration $)$ and are representative of three independent experiments.
According to published guidelines, IC $50<10 \mu \mathrm{g} /$ $\mathrm{mL}$ represents potentially 'very toxic'; IC50 10-100 $\mu \mathrm{g} /$ $\mathrm{mL}$ represents 'potentially toxic'; IC50 100-1000 $\mu \mathrm{g} /$ $\mathrm{mL}$ represents 'potentially harmful' and IC50>1000 $\mu \mathrm{g} / \mathrm{mL}$ represents 'potentially nontoxic' (Gad-Shayne, 2009). Based on these data, it is possible to infer that EO obtained from $P$. emarginatus may be considered very to potentially toxic. Nowadays, an increasing body of evidence has emerged indicating that pure compounds obtained from plant extracts are used in cancer treatment, such as campothecin. Furthermore, medicinal plants are largely used worldwide by the population and have proved to be a rich source of new active compounds, such as new anticancer molecules (Calixto et al., 2004; Costa et al., 2008). In fact, Kaileh et al. (2007) evaluated the potentiality against cancer cell lines of 24 plants from Palestine, and found IC50 values varying from 55 to 2000 $\mu \mathrm{g} / \mathrm{mL}$. More recently, Fiore et al. (2006) have analyzed six different species of Salvia and found moderate activity ranging from 89.6 to $405.1 \mu \mathrm{g} / \mathrm{mL}$. Also of interest are the results from the other group showing that pure substances show low values in MTT cytotoxic assay, ranging from 0.1 to $10 \mu \mathrm{g} / \mathrm{mL}$, for instance, jacaranone, a quinoid isolated from Senecio ambiguous had values of IC50 from 4.32 to $7.39 \mu \mathrm{g} / \mathrm{mL}$ (Loizzo et al., 2007). In addition, another recent and relevant publication has shown that berberine and coptisine isolated from Coptis chinensis showed IC50 values ranged from 0.6 to $15.2 \mu \mathrm{g} / \mathrm{mL}$ (Lin et al., 2004). A previous report showed the toxicity of seed's oil of a synonymy species $P$. pubescens on PBMC, and the authors found a cytotoxic effect with IC $502.0 \mu \mathrm{g} / \mathrm{mL}$ for these cells (Sabino et al., 1999). Very recently, an interesting study conducted by Vieira et al. (2008) has demonstrated the cytotoxicity, morphological and biochemical alterations on human melanoma cells (cell line SK MEL 37) induced by vouacapan-derived compound isolated from EO of P. pubescens seeds. These results have led authors to conclude that diterpenoids vouacapan could be used as a model to develop new anticancer agents. This evidence has

Table 3. In vitro cell viability assay of EO of Pterodon emarginatus seeds in peripheral blood mononuclear cells (PBMC).

\begin{tabular}{|c|c|c|c|c|}
\hline \multirow{2}{*}{ Treatment } & \multirow{2}{*}{ Concentration $(\mu \mathrm{g} / \mathrm{mL})$} & \multicolumn{3}{|c|}{ Viability (\%) } \\
\hline & & $12 \mathrm{~h}$ & $24 \mathrm{~h}$ & $48 \mathrm{~h}$ \\
\hline Control (Medium) & - & $100 \pm 5.5$ & $100 \pm 4.7$ & $100 \pm 3.5$ \\
\hline \multirow[t]{3}{*}{$\mathrm{EO}$} & 1 & $97 \pm 2.5$ & $98 \pm 1.5$ & $96 \pm 3.2$ \\
\hline & 10 & $96 \pm 1.3$ & $95 \pm 2.9$ & $97 \pm 2.2$ \\
\hline & 100 & $94 \pm 1.5$ & $93 \pm 3.5$ & $95 \pm 3.3$ \\
\hline \multirow[t]{3}{*}{ DOXO } & 1 & $50 \pm 3.8 * *$ & $68 \pm 4.3 * *$ & $44 \pm 4.5^{* *}$ \\
\hline & 10 & $16 \pm 8.1 * *$ & $23 \pm 5.7 * *$ & $17 \pm 4.8 * *$ \\
\hline & 100 & $7 \pm 2.1 * *$ & $4 \pm 2.3 * *$ & $5 \pm 3.2 * *$ \\
\hline
\end{tabular}

PBMC $\left(1 \times 10^{5}\right.$ cells $\left./ \mathrm{mL}\right)$ were treated with different concentrations of EO $(1-100 \mu \mathrm{g} / \mathrm{mL})$ and the cells were tested for viability by MTT assay after the treatment of EO and Doxorubicin (DOXO, 1-100 $\mu \mathrm{g} / \mathrm{mL}$ ) for 12,24 and $48 \mathrm{~h}$. The value represented the mean \pm S.D from two independent experiments. ${ }^{* *} p<0.01$ significantly different from the control value 
been further extended by recent results showing that $6 \alpha$, $7 \beta$-hydroxyvouacapan-17 $\beta$-lactone inhibited the growth of human cancer cells (Euzébio et al., 2009). Herein, our data showed that EO obtained from P. emarginatus seeds markedly induced in vitro cytotoxicity to a number of human/rodents tumour cell lines.

In fact, our data extends the results of recent reports which indicated that bicyclic sesquiterpenoids, such as $(+)$-spathulenol, $\alpha$-pinene, globulol, viridiflorene and eremophilanes exhibited cytotoxicity against P388D-1 mouse lymphoblast cells in vitro (Beattie et al., 2011). Another recent and relevant publication has shown that the leaf EO of Oreopanax nubigenus and Schefflera rodrigueziana was dominated by the sesquiterpene hydrocarbons germacrene-D (70.1 and 27.6\%) and transcaryophyllene (11.8 and $12.2 \%)$, respectively. Moreover, both $O$. nubigenus and $S$. rodrigueziana leaf oils showed notable in vitro cytotoxicity on MDA-MB 231 cells, which have led authors to conclude that antiproliferative effect presented by EO may be attributable to the relatively high concentrations of germacrene-D and transcaryophyllene in those oils (Richmond et al., 2009). A very interesting report has shown that $\alpha$-humulene and transcaryophyllene, constituents of $P$. emarginatus EO, were found in other plants (Saroglou et al., 2006). However, Loizzo et al. (2007) identified in their extract the presence of $\alpha$-humulene, suggesting it to be one (but not the only) molecule responsible for its cytotoxic activity in rectal and prostate carcinoma. Here, we demonstrated that EO administration suppressed, mainly, rat glioma $\left(\mathrm{C}_{6}\right)$ and human melanoma (MeWo), among other cells. Therefore, it is tempting to suggest that sesquiterpene compounds, such as trans-caryophyllene, $\beta$-elemene, germacrene-D and $\alpha$-humulene present in the EO may, at least in part, explain how EO attenuates growth of tumor cells in vitro. However, whether these individual compounds inhibit the growth of tumor cells in vitro or in vivo requires further investigation. In addition, our data further extend the notion that EO obtained from P. emarginatus seeds have significant pharmacological activities, such as antinociceptive, antimicrobial and anti-inflammatory activities (Dutra et al., 2008; Dutra et al., 2009a; Dutra et al., 2009b).

\section{Conclusion}

In summary, the data obtained in this study revealed that the EO obtained from $P$. emarginatus seeds showed lower cytotoxicity in normal cells, but it exerted higher cytotoxic activity toward the cancer cells. Our data also showed the chemical composition of EO, as well as preliminary toxicity in A. salina. Moreover, the EO may be acting at least partially by inhibits the apoptosis pathway. Therefore, it seems reasonable to suggest that EO obtained from P. emarginatus seeds or its constituents may represent, in the near future, a new therapeutic option for the development of new drug for cancer treatment. Further studies aiming to investigate which compounds in the EO are responsible for the described antiproliferative activity and the precise mechanisms of action are underway.

\section{Acknowledgements}

This work was supported by grants from the CNPq and the CAPES. RCD, DDJ and RM are D.Sc. students in pharmacology with a scholarship from CNPq.

\section{References}

Adams R 1995. Identification of essential oil components by gas chromatography/mass spectroscopy. Illinois: Allured Publishing Corporation.

Ajaiyeoba EO, Abiodun OO, Falade MO, Ogbole NO, Ashidi JS, Happi CT, Akinboye DO 2006. In vitro cytotoxicity studies of 20 plants used in Nigerian antimalarial ethnomedicine. Phytomedicine 13: 295-298.

Arriaga AMC, Castro MAB, Silveira ER, Braz-Filho R 2000. Further diterpenoids isolated from Pterodon polygalaeflorus. J Brazil Chem Soc 11: 187-190.

Bakkali F, Averbeck S, Averbeck D 2008. Biological effects of essential oils. Food Chem Toxicol 46: 446-475.

Beattie KD, Waterman PG, Forster PI, Thompson DR, Leach DN 2011. Chemical composition and cytotoxicity of oils and eremophilanes derived from various parts of Eremophila mitchellii Benth. (Myoporaceae). Phytochemistry 72: 400-408.

BoehmeAK, Noletto JA, HaberWA, SetzerWN2008. Bioactivity and chemical composition of the leaf essential oils of Zanthoxylum rhoifolium and Zanthoxylum setulosum from Monteverde, Costa Rica. Nat Prod Res 10: 31-36.

Braz-Filho R, Gottlieb OR, Assumpção RMV 1971. The isoflavones of Pterodon pubescens. Phytochemistry 10: 2835-2836.

Brito ARMS, Brito AAS 1993. Forty years of Brazilian medicinal plant research. J Ethnopharmacol 39: 53-67.

Brown JM, Wouters BG 1999. Apoptosis, p53, and tumour cell sensitivity to anticancer agents. Cancer Res 59: 13911399.

Burden DA, Osheroff $\mathrm{N}$ 1998. Mechanism of action of topoisomerase II and drugs targeted to the enzyme. Biochim Biophys Acta 1400: 139-154.

Buyukleyla M, Rencuzogullari E 2009. The effects of thymol on sister chromatid exchange, chromosome aberration and micronucleus in human lymphocytes. Ecotox Environ Safe 72: 943-947.

Calixto JB, Campos MM, Otuki MF, Santos AR 2004. Antiinflammatory compounds of plant origin. Part II. Modulation of pro-inflammatory cytokines, chemokines 
and adhesion molecules. Planta Med 70: 93-103.

Carvalho JCT 2004. Fitoterápicos antiinflamatórios: aspectos químicos, farmacológicos e aplicações terapêticas. Ribeirão Preto: Tecmedd.

Costa PM, Ferreira PMP, Bolzani VS, Furlan M., Santos VAFFM, Corsino J 2008. Antiproliferative activity of pristimerin isolated from Maytenus ilicifolia (Celastracea) in human HL-60 cells. Toxicol in vitro 22: 854-863.

Cragg GM, Boyd MR, Cardellina IIJH, Newman DJ, Snader KM, McCloud TG 1994. Ethnobotanic and drug discovery: the experience of the US National Cancer Institute. In: Ethnobotanic and Search for New Drugs. Ciba Foundation Symposium 185. John Wiley \& Sons: Chichester, p. 178-196.

De Medeiros MG, Da Silva AC, Citó AM, Borges AR, De Lima SG, Lopes JA, Figueiredo RC 2011. In vitro antileishmanial activity and cytotoxicity of essential oil from Lippia sidoides Cham. Parasitol Int 60: 237-241.

Denizot F, Lang R 1986. Rapid colorimetric assay for cell growth and survival- modification to the tetrazolium dye procedure giving improved sensitivity and reliability. $J$ Immunol Methods 89: 271-277.

Dos Santos Filho D, Vichnewski W, Baker PM, Gilbert B 1972. Prophylaxis of Schistosomiaris diterpenes from Pterodon pubenscens. An Acad Bras Cienc 44: 45-49.

Duarte IDG, Ferreira-Alves DL, Veloso DP, Nakamura-Craig M 1996. Evidence of the involvement of biogenic amines in the antinociceptive effect of a vouacapan extracted from Pterodon polygalaeflorus Benth. $J$ Ethnopharmacol 55: 13-18.

Dutra RC, Braga FG, Coimbra ES, Silva AD, Barbosa NR 2009a. Antimicrobial and leishmanicidal activities of seeds of Pterodon emarginatus. Rev Bras Farmacogn 19: 429-435.

Dutra RC, Fava MB, Alves CCS, Ferreira AP, Barbosa, NR 2009b. Antiulcerogenic and anti-inflammatory activities of the essential oil from Pterodon emarginatus seeds. $J$ Pharm Pharmacol 61: 243-250.

Dutra RC, Trevizani R, Pittella F, Barbosa NR 2008. Antinociceptive activity of the essential oil and fractions of Pterodon emarginatus Vogel seeds. Lat Am J Pharm 27: 865-870.

El-Sayed MM, El-Hashash MM, Mohamed MA, Korany TM 2011. Cytotoxic activity of Vitex trifolia purpurea extracts. J Egypt Soc Parasitol 41: 409-416.

Euzébio FP, Dos Santos FJ, Piló-Veloso D, Ruiz AL, De Carvalho JE, Ferreira-Alves DL, De Fátima A 2009. Effect of $6 \alpha, 7 \beta$-dihydroxyvouacapan-17 $\beta$-oic acid and its lactone derivatives on the growth of human cancer cells. Bioorg Chem 37: 96-100.

Fascio M, Mors WB, Gilbert B, Mahajan JR, Monteiro MB, Dos Santos Filho D, Vichenewski W 1976. Diterpenoid Furans from Pterodon species. Phytochemistry 15: 201203.
Fiore G, Nencini C, Carvallo F, Capasso A, Bader A, Giorgi G, Micheli L 2006. In vitro antiproliferative effect of six Salvia species on human tumor cell lines. Phytother Res 20: 701-703.

Gad-Shayne C 2009. Alternatives to in vivo studies in toxicology. In: Ballantyne B, Marrs TC, Syversen TLM, General and Applied Toxicology. v.6, John Wiley \& Sons Inc.

Huang Y, Chuang A, Hao H, Talbot C, Sen T, Trink B, Sidransky D, Ratovitski E 2011. Phospho- $\delta$-Np63- $\alpha$ is a key regulator of the cisplatin-induced microRNAome in cancer cells. Cell Death Differ 18: 1220-1230.

Kaileh M, Berghe WV, Boone E, Essawi T, Haegeman G 2007. Screening of indigenous Palestinian medicinal plants for potential anti-inflammatory and cytotoxic activity. $J$ Ethnopharmacol 113: 510-516.

Kamuhabwa A, Nshimo C, De Witte P 2000. Cytotoxicity of some medicinal plant extracts used in Tanzanian traditional medicine. J Ethnopharmacol 70: 143-149.

Kaufman SH 1998. Cell death induced by topoisomerasetargeted drugs: more questions than answers. Biochim Biophys Acta 1400: 195-211.

Lin CC, NG LT, Hsu FF, Shieh DE, Chinag LC 2004. Cytotoxic effects of Coptis chinensis and Epimedium sagittatum extracts and their major constituents (berberine, coptisine and icariin) on hepatoma and leukaemia cell growth. Clin Exp Pharmacol P 31: 65-69.

Litchfield JT, Wilcoxon F 1949. A simplified method of evaluating dose-effect experiments. J Pharmacol Exp Ther 96: 99-113.

Loizzo MR, Tundis R, Statti GA, Menichini F 2007. Jacaranone: a cytotoxic constituent from Senecio ambiguus subsp. ambiguus (biv.) DC. against renal adenocarcinoma ACHN and prostate carcinoma LNCaP cells. Arch Pharm Res 30: 701-707.

Lorenzi H, Matos FJA 2002. Plantas medicinais no Brasil: nativas e exóticas. São Paulo: Instituto Plantarum.

Lukas B, Schmiderer C, Franz C, Novak J 2009. Composition of essential oil compounds from different Syrian populations of Origanum syriacum L. (Lamiaceae). $J$ Agric Food Chem 25: 1362-1365.

Marques DD, Machado MIL, Carvalho MG, Meleira LAC, Braz-Filho R 1998. Isoflavonoids and triterpenoids isolated from Pterodon polygalaeflorus. J Brazil Chem Soc 9: 295-301.

McLaughlin JL, Rogers LL 1998. The use of biological assays to evaluate botanicals. Drug Inf J 32: 513-524.

Meyer BN, Ferrigni NR, Putnam JE, Jacobsen LB, Nichols DE, McLaughlin JL 1982. Brine Shrimp: A convenient general bioassay for active plant constituents. Planta Med 45: 31-34.

Nwodo UU, Ngene AA, Anaga AO, Chigor VN, Henrietta II, Okoh AI 2011. Acute toxicity and hepatotoxicokinetic studies of Tamarindus indica extract. Molecules 31: 7415-7427. 
Pereira MF, Martino T, Dalmau SR, Albano RM, Férézou JP, Costa SS, Coelho MG, Sabino KG 2011. Terpenic subfraction of Pterodon pubescens induces apoptosis of K562 leukemic cells by modulating gene expression. Oncol Rep 25: 215-221.

Pimenta LPS, Pinto GB, Takahashi JA, Silva LGF, Boaventura MAD 2003. Biological screening of Annonaceous brazilian medicinal plants using Artemia salina (Brine Shrimp Test). Phytomedicine 10: 209-212.

Qu XJ, Cui SX, Tian Z, Li X, Chen MH, Xu WF, Inagaki Y, Deng YB, Makuuchi M, Nakata M 2007. Induction of apoptosis in human hepatocellular carcinoma cells by synthetic antineoplaston A10. Anticancer Res 27: 24272431 .

Richmond JD, Agius BR, Wright BS, Haber WA, Moriarity DM, Setzer WN 2009. Essential oil compositions and cytotoxic activities of Dendropanax capillaris, Oreopanax nubigenus, and Schefflera rodrigueziana from Monteverde, Costa Rica. Nat Prod Commun 4: 271-274

Rivest P, Renaud M, Sanderson JT 2011. Proliferative and androgenic effects of indirubin derivatives in LNCaP human prostate cancer cells at sub-apoptotic concentrations. Chem-Biol Interact 189: 177-185.

Sabino KCC, Gayer CRM, Vaz LCA, Santos LRL, Felzenszwal I, Coelho MGP 1999. In vitro and in vivo toxicological study of the Pterodon pubescens seed oil. Toxicol Lett 108: 27-35.

Saroglou V, Dorizas N, Kypriotakis Z, Skaltsa HD 2006. Analysis of the essential oil composition of eight Anthemis species from Greece. J Chromatogr 1104: 313-322.

Silva MCC, Gayer CRM, Lopes CS, Calixto NO, Reis PA,
Passaes C.B, Paes MC, Dalmau SR, Sabino KCC, Tedeschini AR, Coelho MGP 2004. Acute and topic anti-edematogenic fractions isolated from the seeds of Pterodon pubescens. J Pharm Pharmacol 55: 135-141.

Singal PK, Iliskovic N 1998. Doxorubicin-induced cardiomyopathy. New Engl J Med 339: 900-905.

Stammati A, Bonsi P, Zucco F, Moezelaar R, Alakomi HL, Von Wright A 1999. Toxicity of selected plant volatiles in microbial and mammalian short-term assays. Food Chem Toxicol 37: 813-823.

Torrenegra R, Bauereib P, Achenbach H 1989. Homoormosanine-type alkaloids from Bowdichia virgiloides. Phytochemistry 28: 2219-2221.

Vieira CR, Marques MF, Soares PR, Matuda L, De Oliveira CMA, Kato L, Da Silva CC, Guillo LA 2008. Antiproliferative activity of Pterodon pubescens Benth. seed oil and its principle on human melanoma cells. Phytomedicine 15: 528-532.

Weiss RB 1992. The anthracyclines: will we ever find a better doxorubicine. Semin Oncol 19: 670-686.

Yoo HH, Park JH, Kwon SW 2007. In vitro cytotoxic activity of some korean medicinal plants on human cancer cell lines: enhancement in cytotoxicity by heat processing. Phytother Res 9: 900-903.

\section{*Correspondence}

Rafael C. Dutra

Departamento de Farmacologia, Universidade Federal de Santa Catarina

88049-900 Florianópolis-SC, Brazil

rafael.d@posgrad.ufsc.br

Tel.: + 55-48-37219491 